\title{
Passive Transfer of Immediate Hypersensitivity and Airway Hyperresponsiveness by Allergen-specific Immunoglobulin (Ig) E and IgG1 in Mice
}

\author{
Akihiro Oshiba, Eckard Hamelmann, Katsuyuki Takeda, Katherine L. Bradley, Joan E. Loader, Gary L. Larsen, \\ and Erwin W. Gelfand \\ Divisions of Basic Sciences and Pulmonary Medicine, Department of Pediatrics, National Jewish Center for Immunology and Respiratory \\ Medicine, Denver, Colorado 80206
}

\begin{abstract}
In a proportion of atopic asthmatics, exposure to a relevant antigen is followed by chronic inflammation in the airways leading to altered airway responsiveness (AR). However, the mechanisms underlying the development of airway hyperresponsiveness still remain unclear. To elucidate the relationship between IgE-mediated reactions and airway hyperresponsiveness, a murine model of passive sensitization and airway challenge with ovalbumin (OVA) was developed using anti-OVA IgE and IgG antibodies from murine B cell hybridomas. Passive sensitization by intravenous injection of anti-OVA IgE resulted in immediate cutaneous hypersensitivity and, after airway challenge with OVA on two consecutive days, increased AR in BALB/c and SJL mice. Increased numbers of eosinophils were observed in bronchoalveolar lavage fluid, in cells extracted from the lungs, and in the peribronchial areas of BALB/c mice passively sensitized with IgE and challenged through the airways compared with nonsensitized mice. Eosinophil peroxidase activity was also elevated in lung tissue from these mice. Passive sensitization with anti-OVA IgG1 but not IgG2a or IgG3 was similarly associated with development of skin test reactivity and increased AR after airway challenge, accompanied by an increase in eosinophils in bronchoalveolar lavage fluid. These data suggest that IgE/IgG1-mediated reactions together with local challenge with antigen can result in allergic inflammation resulting in altered airway function. (J. Clin. Invest. 1996. 97:1398-1408.) Key words: eosinophils - monoclonal IgE antibody - monoclonal IgG1 antibody - immediate cutaneous hypersensitivity - airway responsiveness
\end{abstract}

\section{Introduction}

It is generally accepted that, in allergic diseases such as asthma, allergen-specific IgE plays a primary role in immediate hypersensitivity reactions, and that such IgE-mediated re-

Address correspondence to Dr. Erwin W. Gelfand, Department of Pediatrics, National Jewish Center for Immunology and Respiratory Medicine, 1400 Jackson Street, Denver, CO 80206. Phone: 303-3981196; FAX: 303-270-2105.

Received for publication 31 August 1995 and accepted in revised form 5 January 1996.

J. Clin. Invest.

(C) The American Society for Clinical Investigation, Inc. 0021-9738/96/03/1398/11 \$2.00

Volume 97, Number 6, March 1996, 1398-1408 actions are followed by chronic inflammation leading to increased airway responsiveness $(A R)^{1}$ (1). However, the relationship between immediate hypersensitivity reactions triggered by $\operatorname{IgE}$ and subsequent allergic inflammation resulting in airway hyperresponsiveness is not fully defined. Whereas cross-linking of specific IgE bound to mast cells by allergens initially provides specificity to the subsequent sequence of reactions, increasing evidence indicates that $\mathrm{T}$ cells, especially $\mathrm{T}$ helper type 2 cells, also participate in chronic inflammation (2). Immunohistochemical studies have shown increased numbers of activated $\mathrm{T}$ cells in local inflammatory lesions in allergic diseases $(3,4)$. After challenge with antigen, increased expression of mRNA encoding T helper type 2-associated cytokines has been demonstrated in sites where allergic inflammation developed $(5,6)$.

We developed a murine model of allergic sensitization in which BALB/c mice, exposed to an aerosolized antigen, develop antigen-specific IgE, immediate cutaneous hypersensitivity, and increased AR to either intravenous methacholine (7) or electrical field stimulation $(8,9)$. In most animal models of allergic sensitization, including our approach with aerosolized antigen exposure, altered AR was always accompanied by elevated levels of antigen-specific $\operatorname{IgE}$ in the serum $(10,11)$. However, these observations do not necessarily invoke a causal association between antigen-specific IgE and airway hyperresponsiveness, especially since repeated challenges with antigen are required for these responses. Whether IgE-mediated reactions are necessary or sufficient for the development of airway hyperresponsiveness remains to be determined, as does the definition of the role of antigen-specific $\mathrm{T}$ cells recruited to local sites.

Previous investigations have suggested the presence of alternative pathways for triggering immediate hypersensitivity (12). Murine IgG1 is capable of sensitizing murine mast cells, independently of $\mathrm{IgE}$, although $\mathrm{IgG}$ subclass antibodies may also interfere with mast cell sensitization to $\operatorname{IgE}(13,14)$. There is a possibility that allergen-specific $\operatorname{IgG} 1$, induced in sensitized animals, mediates not only immediate hypersensitivity but also airway hyperresponsiveness.

To define these relationships between allergen-specific IgE-mediated responses and airway hyperresponsiveness further and to explore the ability of IgG subclass antibodies to elicit hypersensitivity responses, we generated murine $\mathrm{B}$ cell hybridomas secreting ovalbumin (OVA)-specific IgE and $\mathrm{IgG}$

1. Abbreviations used in this paper: AR, airway responsiveness; BAL, bronchoalveolar lavage; EPO, eosinophil peroxidase; $\mathrm{ES}_{50}$, electrical stimulation resulting in 50\% maximal contraction; KLH, keyhole limpet hemocyanin; OVA, ovalbumin; PCA, passive cutaneous anaphylaxis; TNP, trinitrophenyl. 
subclass antibodies. We performed passive transfer experiments with these mAbs, monitoring immediate cutaneous reactivity and changes in AR after airway challenge. This approach provides an excellent means for analyzing the effects of allergen-specific IgE or IgG subclass antibodies on both immediate hypersensitivity reactions and airway hyperresponsiveness. In this study, we show that passive sensitization with both OVA-specific IgE and IgG1 causes immediate cutaneous hypersensitivity and played an essential role in the development of airway hyperresponsiveness after specific antigen challenge via the airways.

\section{Methods}

Animals. Female BALB/c and SJL/J mice 8-12 wk of age were obtained from The Jackson Laboratory (Bar Harbor, ME). The mice were maintained on OVA-free diets. All experimental animals used in this study were under a protocol approved by the Institutional Animal Care and Use Committee of the National Jewish Center for Immunology and Respiratory Medicine.

Antigens. OVA (grade V; Sigma Chemical Co., St. Louis, MO) was used for immunization and airway challenge. Trinitrophenyl (TNP)-keyhole limpet hemocyanin (KLH) (Boehringer Mannheim Corp., Indianapolis, IN) conjugate was prepared as previously described (15). Total protein concentration of the conjugate and hapten/carrier ratio was determined by spectrophotometric measurement. The product had a molar ratio of $960 \mathrm{TNP} / \mathrm{KLH}$. BSA (grade V; Sigma Chemical Co.) was used as control antigen for skin testing and airway challenge.

Immunization and cell preparation. $\mathrm{BALB} / \mathrm{c}$ mice were immunized intraperitoneally with $10 \mu \mathrm{g}$ OVA absorbed on $2.25 \mathrm{mg}$ alum (Imject Alum; Pierce, Rockford, IL) two times over 2 wk. 1 wk after the last immunization, spleens were removed and mononuclear cells were purified by dispersing small tissue pieces through stainless steel mesh followed by density gradient centrifugation (Lymphocyte Separation Medium; Organon Teknika, Durham, NC). The cells were washed three times with PBS and resuspended in RPMI 1640 medium (GIBCO BRL, Gaithersburg, MD).

Generation of anti-OVA antibody-secreting hybridoma cell lines. The aminopterin-sensitive myeloma cell line SP2/0, which produces no Ig chains (American Type Culture Collection [ATCC], Rockville, MD) was grown in RPMI 1640 medium supplemented with $15 \%$ heat-inactivated bovine calf serum (HyClone Laboratories, Logan, UT), $5 \mathrm{mM}$ L-glutamine, $0.05 \mathrm{mM}$ 2-mercaptoethanol, $100 \mathrm{U} / \mathrm{ml}$ penicillin, and $100 \mu \mathrm{g} / \mathrm{ml}$ streptomycin (all from GIBCO BRL). Established hybridomas were cultured in the same medium. All cultures were maintained at $37^{\circ} \mathrm{C}$ in a humidified atmosphere containing $5 \% \mathrm{CO}_{2}$.

Spleen cells from BALB/c mice immunized with OVA were fused with myeloma cells as described previously (16) with some minor modifications. Briefly, $1 \times 10^{8}$ spleen cells were resuspended in $0.1 \mathrm{ml}$ serum-free medium with $3 \times 10^{7}$ myeloma cells; $0.5 \mathrm{ml} 50 \%$ polyethylene glycol, molecular weight 4,000 (ATCC) in PBS, was added to the cell pellet slowly for $2 \mathrm{~min}$; and then cells were centrifuged for $3 \mathrm{~min}$ at $100 \mathrm{~g}$. The polyethylene glycol was diluted with $8 \mathrm{ml}$ serum-free medium, and then bovine calf serum was added to a final concentration of $15 \%$. The cells were placed into a tissue culture dish in the presence of $200 \mathrm{U} / \mathrm{ml}$ murine IL-4 (kindly provided by Dr. Paul Trotta, Schering-Plough, Bloomfield, NJ). After $6 \mathrm{~h}$, the cells were diluted and seeded into six 96-well microplates $(150 \mu \mathrm{l} /$ well $) .1 \mathrm{~d}$ after fusion, $100 \mu \mathrm{l}$ of selective medium containing $50 \mu \mathrm{g} / \mathrm{ml}$ hypoxanthine and $4 \mu \mathrm{g} / \mathrm{ml}$ azaserine was added to each well. Supernatants of wells with growing hybridoma cells were screened 1-2 wk after cell fusion for anti-OVA IgE and IgG antibodies by ELISA assays as described below. Hybridoma cells secreting anti-OVA antibodies were recloned several times by limiting dilution. OVA-specific subclones from culture plates with cell growth in $<30 \%$ of all wells were se- lected, transferred to a 24-well culture plate, and cultured for 7-10 d; supernatants were harvested and pooled. Hybridoma cell lines producing monoclonal anti-TNP IgE and IgG1 antibodies (ATCC) were also used as a source of specific antibodies.

Measurement of anti-OVA antibody and total Ig levels. Anti-OVA $\mathrm{IgE}$ and $\mathrm{IgG}$ antibody levels in culture supernatants of hybridomas and serum were assayed by ELISA as previously described (9). The antibody titers of the samples were related to pooled standards that were generated in the laboratory and deliberately assigned to be 100 $\mathrm{U} / \mathrm{ml}$. Wells containing supernatants with $>100 \mathrm{U} / \mathrm{ml}$ of anti-OVA were selected as positive for screening hybridomas. Total IgE, IgG, IgG1, IgG2a, and IgG3 levels were determined using the same method in plates coated with sheep anti-mouse IgE or IgG antibodies (The Binding Site Inc., San Diego, CA) and adding alkaline phosphatase-conjugated rat anti-mouse IgE, IgG1, IgG2a, IgG3 (PharMingen, San Diego, CA), or sheep anti-mouse IgG. Total Ig levels were calculated by comparison with known mouse $\mathrm{IgE}, \mathrm{IgG}$, and each IgG subclass standards (PharMingen). The limit of detection was 100 $\mathrm{pg} / \mathrm{ml}$ for $\mathrm{IgE}$ and $1 \mathrm{ng} / \mathrm{ml}$ for $\mathrm{IgG}$ and each IgG subclass.

Antibody-binding assays as a measure of functional affinity. Direct binding assays were carried out in a microtiter plate coated with OVA as described above in antigen-specific ELISA to determine functional affinities of antibodies secreted by OVA-specific hybridomas. Twofold dilutions of supernatants containing anti-OVA IgE or $\mathrm{IgG}$ isotypes were added at concentrations ranging from 15.6 to 2,000 $\mathrm{ng} / \mathrm{ml}$. Bound antibodies were detected using alkaline phosphataseconjugated sheep anti-mouse $\operatorname{IgG}(\mathrm{Fc})$ antibody (The Binding Site Inc.), or biotinylated anti-mouse $\kappa$ chain antibody (kindly provided by Dr. L. Wysocki, National Jewish Center, Denver, CO) and alkaline phosphatase-conjugated avidin (PharMingen). After adding alkaline phosphatase substrate, resulting OD $(410 \mathrm{~nm})$ values were determined with an ELISA reader. Antibody concentrations were determined by total Ig ELISA, as described above.

Passive cutaneous anaphylaxis $(P C A)$ reaction. The PCA reaction using culture supernatants was performed with $\mathrm{BALB} / \mathrm{c}$ mice as described (13). Samples, $30 \mu \mathrm{l} \mathrm{of} \log _{2}$ dilutions of supernatants, were injected intracutaneously on the shaved abdomen. After 1-2 d, the animals were challenged with an intravenous injection of $0.2 \mathrm{ml}$ of a solution containing $5 \mathrm{mg} / \mathrm{ml} \mathrm{OVA}$ or TNP-KLH in PBS and $1 \%$ Evans blue. After $30 \mathrm{~min}$, the bluing reaction was read. PCA titers are expressed as the $\log _{2}$ of a reciprocal value of the highest dilution providing a PCA reaction.

Passive sensitization with monoclonal anti-OVA antibodies and airway challenge with aerosolized OVA. Mice (three to four mice per group per experiment) were passively sensitized by intravenous injection of a hybridoma supernatant containing anti-OVA antibodies. Groups of mice received an injection on two consecutive days with hybridoma supernatant containing $2 \mu \mathrm{g}$ anti-OVA IgE, IgG1, IgG2a, or IgG3 in a volume of $200 \mu$ l. The original pools of supernatants had a range of Ig concentrations from 10 to $20 \mu \mathrm{g} / \mathrm{ml}$ (as measured by isotype specific ELISA) and were diluted with PBS to a concentration of $10 \mu \mathrm{g} / \mathrm{ml}$ to standardize each injection of the various mAbs. We established three different hybridoma cell lines secreting OVA-specific IgE. Each anti-OVA IgE hybridoma showed approximately equal titers as determined by ELISA for OVA-specific IgE when adjusted for total IgE content and were equivalent in PCA reactions. Preliminary experiments, in which $\mathrm{BALB} / \mathrm{c}$ mice received up to five injections of each hybridoma supernatants, showed that at least two injections of $2 \mu \mathrm{g}$ anti-OVA IgG1 were necessary to obtain positive immediate cutaneous hypersensitivity reactions consistently, while a single injection of $2 \mu \mathrm{g}$ anti-OVA IgE was sufficient for developing positive skin test responses $7 \mathrm{~d}$ later. Age-matched control mice received culture supernatants of the parental myeloma cell line or hybridomas secreting anti-TNP IgE, anti-OVA IgG2a, or anti-OVA IgG3, following the same protocol. The passively sensitized mice were exposed to nebulized OVA ( $1 \% \mathrm{wt} / \mathrm{vol}$ diluted in PBS) for 20 min daily, 3 and $4 \mathrm{~d}$ after the last injection of antibody. This interval between the injections of IgE, airway challenge and monitoring of 
AR was determined to be optimal for demonstrating specific changes in airway function. As a positive control group, some mice were actively sensitized with two intraperitoneal injections of OVA plus alum as described above. These mice were also challenged with nebulized OVA 6 and $7 \mathrm{~d}$ after the second intraperitoneal injection. 1-2 d after the last airway challenge, skin testing and AR were performed and evaluated by an investigator who was blinded to the sensitization and treatment status of the animals.

Analysis of immediate cutaneous hypersensitivity and systemic anaphylaxis. Development of immediate cutaneous hypersensitivity to OVA in passively sensitized mice was assessed by intradermal skin testing as described previously (9). The abdomen of the mouse was shaved and $20 \mu \mathrm{l}$ of test solution was injected intradermally with a 30gauge needle. Test solutions were OVA diluted in PBS at a concentration of $500 \mu \mathrm{g} / \mathrm{ml}$, with PBS as the negative control, and $500 \mu \mathrm{g} / \mathrm{ml}$ of BSA in some experiments. Subsequent wheal reactions were assessed after $15 \mathrm{~min}$ and were scored as positive if the wheal diameter was $>5 \mathrm{~mm}$ in any direction. The actual size of the wheal response was measured.

Passive sensitization was also performed to induce a systemic anaphylaxis reaction. Mice were challenged by intravenous administration of $500 \mu \mathrm{g}$ OVA $1 \mathrm{~d}$ after completion of passive sensitization as described above. The animals were monitored for development of acute symptoms for up to $20 \mathrm{~min}$.

Determination of $A R$. Airway smooth muscle responsiveness was determined in vitro as described (17). Briefly, after killing the animals, mouse tracheal rings of $\sim 0.5 \mathrm{~cm}$ in length were sectioned and placed in Krebs-Henseleit baths suspended by triangular supports transducing the force of contractions. Electrical field stimulation was delivered by an S44 stimulator (SIV 5; Grass Instrument Co., Quincy, MA) using 8 V, 2-ms pulse duration, and $0.5-40-\mathrm{Hz}$ frequencies. Each stimulation was maintained until peak contractile responses were obtained. The $40-\mathrm{Hz}$ frequency was established earlier to result in maximal contractions. $\mathrm{ES}_{50}$, the frequency that caused $50 \%$ of maximal contractions, was calculated from linear plots.

Bronchoalveolar lavage $(B A L)$. BAL fluid was obtained and lung perfusion was performed $1 \mathrm{~d}$ after the last exposure to aerosolized OVA. Immediately after killing the animals, the tracheas were intubated with a polyethylene catheter and the lungs were lavaged with $3 \mathrm{ml} \mathrm{HBSS}$. The total number of cells from the recovered BAL fluid was counted with a hemocytometer. Approximately 2.4$2.7 \mathrm{ml}$ of fluid was recovered from each animal. For differential cell counts, slides were prepared with a cytospin (Shandon Scientific, Pittsburgh, PA) and cells were stained with Wright stain (Leukostat; Fisher Diagnostics, Pittsburgh, PA). Aliquots of the BAL fluid were centrifuged and the supernatants were collected and stored at $-20^{\circ} \mathrm{C}$ for measurement of eosinophil peroxidase (EPO) activity.

Preparation of cells from lung tissue. Lung cells were isolated as previously described (18). After performing BAL with $3 \mathrm{ml}$ of HBSS, lungs were perfused with warmed $\left(37^{\circ} \mathrm{C}\right)$ calcium- and magnesiumfree HBSS containing 10\% FCS, $0.6 \mathrm{mM}$ EDTA, $100 \mathrm{U} / \mathrm{ml}$ penicillin, and $100 \mu \mathrm{g} / \mathrm{ml}$ streptomycin via the right ventricle at a rate of $4 \mathrm{ml} /$ min for $4 \mathrm{~min}$. Lungs were removed, cut, and minced through a 300$\mu \mathrm{m}$-wide tissue grid. $4 \mathrm{ml}$ of HBSS containing $175 \mathrm{U} / \mathrm{ml}$ collagenase (type IA; Sigma Chemical Co.), 10\% FCS, $100 \mathrm{U} / \mathrm{ml}$ penicillin, and $100 \mu \mathrm{g} / \mathrm{ml}$ streptomycin were added to the minced lungs and incubated for $60 \mathrm{~min}$ in an orbital shaker at $37^{\circ} \mathrm{C}$. The digested lungs were sheared with a sterile 20 -gauge needle and filtered through $45-\mu \mathrm{m}$ and $15-\mu \mathrm{m}$ filters. Filters were washed with HBSS/ $2 \%$ FCS $(45 \mu \mathrm{m}$, $1 \times 5 \mathrm{ml} ; 15 \mu \mathrm{m}, 2 \times 10 \mathrm{ml})$. Cells were resuspended in HBSS and counted with a hemocytometer, and cytospin slides were made. Slides were stained with Leukostat and cell differentiation percentages were determined, counting at least 200 cells using a light microscope. Remaining cells were pelleted and resuspended in 1\% NP-40 (Sigma Chemical Co.) in distilled water at $2 \times 10^{5}$ cells $/ \mathrm{ml}$, and samples stored at $-20^{\circ} \mathrm{C}$ for measurement of EPO activity.

Lung histology and eosinophil counts. For histologic examination, lung perfusion was performed as described above and 1-2 $\mathrm{ml}$ of for- malin fixing solution was instilled intratracheally after BAL. The lungs were then removed and fixed in formalin solution. One lobe of the lung was embedded in paraffin, and sections of 5- $\mu \mathrm{m}$ thickness were prepared and stained with astra blue and vital new red for staining eosinophil granules as previously described (19). Histologic evaluation of the peribronchial regions of the lung was performed by light microscopy, and tissue slides were examined by an observer in a blind fashion. The number of eosinophils around the bronchi (mucosal and submucosal areas) was counted at a magnification of 400 . Counts were performed using a minimum of ten randomly selected bronchial cross-sections of medium size and expressed per millimeter squared using a computer-assisted graphics program (IP Lab Spectrum; Signal Analytics Co., Vienna, VA).

Determination of EPO activity. Levels of EPO in BAL fluid and the cells extracted from the lungs were determined as previously described (20). Briefly, $100 \mu \mathrm{l}$ of the substrate solution (0.1 mM $o$-phenylene-diamine-dihydrochloride, $0.1 \%$ Triton X-100, $1 \mathrm{mM}$ hydrogen peroxide in $0.05 \mathrm{M}$ Tris- $\mathrm{HCl}$; all reagents from Sigma Chemical Co.) was added to $100 \mu \mathrm{l}$ of sample in microtiter plates and incubated for $30 \mathrm{~min}$ at $37^{\circ} \mathrm{C}$. The reaction was stopped by adding $50 \mu \mathrm{l}$ of $4 \mathrm{M}$ sulfuric acid, and the optical densities were read in a microtiter autoreader at $492 \mathrm{~nm}$. This method has been demonstrated to be specific for eosinophil, since, when using $o$-phenylene-diamine-dihydrochloride as the hydrogen donor, neutrophils show no significant activity (20).

Statistical analysis. A multiple comparison analysis of levels of differences between experimental groups and control conditions was performed using a Dunnett's or Tukey-Kramer HSD test. Values for all measurements are expressed as the mean \pm SD except values for $\mathrm{ES}_{50}$, which are presented as the mean \pm SEM.

\section{Results}

Functional affinities of isotypes secreted by anti-OVA-specific hybridoma clones. Direct immunoassay for antigen-specific antibody has been described using antigen-coupled microtiter plates (21). A variation of this procedure by ELISA was used to measure relative functional affinities of OVA-specific mAbs. Antigen-specific binding for eight anti-OVA IgG hybridoma supernatants was detected by anti-mouse IgG (Fc) antibody (Fig. $1 \mathrm{~A}$ ), and the concentration responsible for $50 \%$ maximal binding was calculated to compare functional affinities among the different isotypes. Since previous studies demonstrated that functional affinities determined by antibody-binding immunoassay are correlated with affinities $\left(K_{\mathrm{a}}\right)$ determined by fluorescence quenching (21), one supernatant showing the lowest $50 \%$ binding point was selected for each isotype for passive sensitization (IgG isotype numbers 1, 4, and 6). The antigen-specific binding was compared between these antiOVA IgG antibodies and anti-OVA IgE (number 8), which were selected for passive sensitization, using anti-mouse $\kappa$ chain antibody (Fig. $1 \mathrm{~B}$ ). Monoclonal anti-OVA antibodies screened in preliminary experiments were shown to bear $\kappa$ light chain. The isotypes chosen for passive sensitization demonstrated relatively equal affinity. None of the isotypes showed significant binding to BSA-coated plates (data not shown).

PCA reaction. The ability of monoclonal anti-OVA antibodies to sensitize mouse skin tissue for antigen-induced immediate hypersensitivity responses was tested by PCA reactions. Serial dilutions (PBS) of hybridoma culture supernatants starting at a concentration of $10 \mu \mathrm{g} / \mathrm{ml}$ of each isotype were used. Both IgE and IgG1 antibodies demonstrated skin-sensitizing capacity (Table I). The PCA titers of the IgE antibody specific for OVA and TNP were higher than the IgG1 anti- 

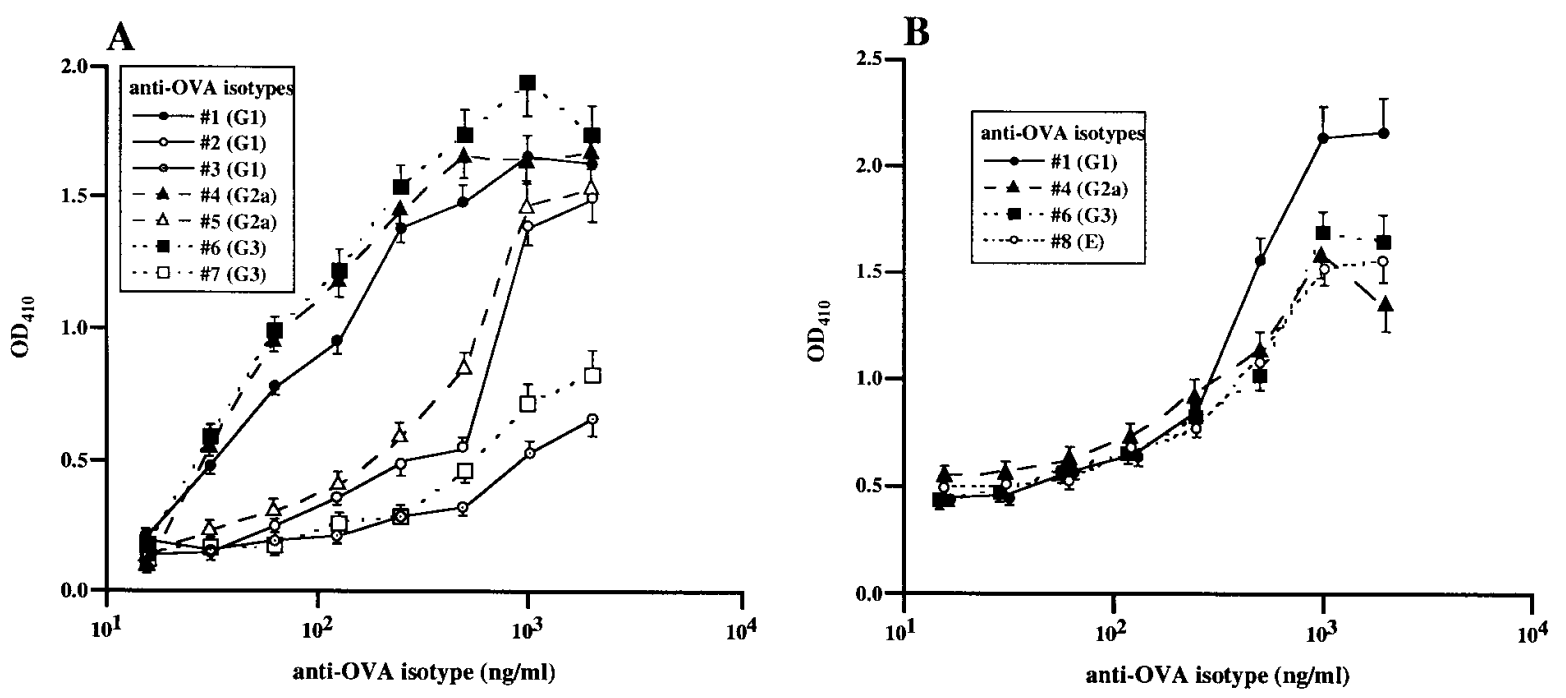

Figure 1. Direct binding analysis of isotypes secreted by OVA-specific B cell hybridomas to OVA. Increasing concentrations of antibodies (numbers 1-8) were analyzed for their ability to bind to OVA-coated plates. Bound antibodies were detected using anti-mouse $\operatorname{IgG}(\mathrm{Fc})(A)$ or anti-mouse $\kappa$ chain antibodies $(B)$. Assays in each condition $(A$ or $B)$ were performed in a single plate. Data are presented as the mean \pm SD of triplicate determinations. The concentrations for $50 \%$ maximal binding calculated by computer-assisted curve fitting to plots of OD vs concentration in Fig. $1 B$ were $520 \mathrm{ng} / \mathrm{ml}$ for the $\mathrm{IgE}$ antibody, $310 \mathrm{ng} / \mathrm{ml}$ for IgG1, $390 \mathrm{ng} / \mathrm{ml}$ for IgG2a, and $510 \mathrm{ng} / \mathrm{ml}$ for IgG3.

body with similar specificity (despite slightly higher affinity), but differences were not significant. The PCA reactions were shown to be antigen specific by using an irrelevant antigen. $\operatorname{IgG} 2 \mathrm{a}$ and $\operatorname{IgG} 3$ antibodies specific for OVA failed to produce a positive PCA reaction, even using concentrations up to 10 $20 \mu \mathrm{g} / \mathrm{ml}$ (data not shown).

OVA-specific antibody and total Ig levels in serum of passively sensitized mice. Serum OVA-specific antibody and total Ig levels were analyzed in mice receiving passive sensitization or active intraperitoneal immunization $1 \mathrm{~d}$ after completion of the nebulization protocol. Whereas anti-OVA $\operatorname{IgE}, \operatorname{IgG} 1$, and $\mathrm{IgG}$ antibody levels were elevated in the serum of intraperitoneally immunized mice, OVA-specific IgE or IgG1 levels were

Table I. PCA Reactions Using Supernatants from Anti-OVA-secreting Hybridomas

\begin{tabular}{llc}
\hline Supernatant & \multicolumn{1}{c}{ Antigen } & PCA titer \\
\hline OVA-IgE & OVA & $9.3 \pm 0.5$ \\
OVA-IgE & TNP-KLH & 0 \\
OVA-IgG1 & OVA & $8.3 \pm 0.5$ \\
OVA-IgG1 & TNP-KLH & 0 \\
TNP-IgE & TNP-KLH & $9.0 \pm 0.8$ \\
TNP-IgE & OVA & 0 \\
TNP-IgG1 & TNP-KLH & $7.0 \pm 0.8$ \\
TNP-IgG1 & OVA & 0 \\
& & \\
\hline
\end{tabular}

PCA titers of supernatants containing IgE and IgG1 antibodies specific for OVA and TNP were determined. Mice receiving intradermal injections with serial dilutions of supernatants were challenged with an intravenous injection of a solution containing specific or irrelevant antigen and Evans blue. PCA titers are expressed as the $\log _{2}$ of the reciprocal value of the highest dilution providing a positive PCA reaction. Presented are the means \pm SD of four mice. significantly higher in mice passively sensitized with supernatants containing the corresponding isotype (subclass) than the intraperitoneally immunized mice (Table II). Mice passively sensitized with anti-OVA IgE showed significantly higher total IgE serum levels than intraperitoneally immunized mice, and no significant differences were observed in total IgG levels among the different treatment groups. Challenge with OVA alone via the airways on two occasions did not affect total IgG or IgE levels, nor did it result in detectable OVA-specific antibodies.

Passively sensitized mice develop antigen-induced immediate cutaneous reactivity and systemic anaphylaxis. As described previously $(8,9)$, sensitization of BALB/c mice to aerosolized antigens such as ragweed and ovalbumin via the airways led to the induction of immediate cutaneous hypersensitivity associated with antigen-specific IgE and IgG production. We deter-

Table II. OVA-specific Antibody and Total Ig Levels in the Serum

\begin{tabular}{|c|c|c|c|c|c|}
\hline \multirow[b]{2}{*}{ Sensitization } & \multicolumn{3}{|c|}{ OVA-specific antibody levels } & \multicolumn{2}{|c|}{ Total Ig levels } \\
\hline & $\operatorname{IgE}$ & IgG1 & $\operatorname{IgG}$ & $\operatorname{IgE}$ & $\mathrm{IgG}$ \\
\hline & & $U / m l$ & & & $n g / m l$ \\
\hline None & $<1$ & $<1$ & $<1$ & $4.7 \pm 1.0$ & $343 \pm 65$ \\
\hline OVA-IgE & $* 169 \pm 33$ & $<1$ & $<1$ & ${ }^{\S} 134 \pm 28$ & $326 \pm 42$ \\
\hline OVA-IgG1 & $<1$ & $¥ 314 \pm 78$ & $26 \pm 11$ & $2.5 \pm 0.6$ & $475 \pm 81$ \\
\hline OVA/alum & $* 82 \pm 13$ & $¥ 65 \pm 16$ & $97 \pm 21$ & $\S 30 \pm 5$ & $562 \pm 103$ \\
\hline
\end{tabular}

Serum titers for OVA-specific antibodies and total Ig were determined by ELISA in mice actively or passively sensitized: nonsensitized control mice $(n=8)$, mice passively sensitized with anti-OVA IgE (OVA-IgE, $n=8$ ) or anti-OVA IgG1 (OVA-IgG1, $n=6$ ), or mice immunized with OVA/alum (OVA/alum, $n=4$ ). Presented are the means \pm SD. ${ }^{*}{ }^{\sharp}$ Significant $(P<0.05)$ differences between the groups. 
Table III. OVA-specific Immediate Cutaneous

Hypersensitivity

\begin{tabular}{llcc}
\hline \multicolumn{1}{c}{ Sensitization } & Nebulization & $\begin{array}{c}\text { Mean wheal } \\
\text { diameter } \pm \text { SD }\end{array}$ & $\begin{array}{c}\text { Number of positive } \\
\text { responders }(\%)\end{array}$ \\
A. BALB/c mice & \multicolumn{3}{c}{$m m$} \\
None & None & $1.9 \pm 0.3$ & $0 / 8(0)$ \\
None & OVA $\times 2$ & $3.1 \pm 0.5$ & $0 / 8(0)$ \\
SP2/0 & OVA $\times 2$ & $3.4 \pm 0.4$ & $0 / 15(0)$ \\
TNP-IgE & OVA $\times 2$ & $4.2 \pm 0.5$ & $1 / 8(12.5)$ \\
OVA-IgE & None & $* 16.8 \pm 0.8$ & $6 / 6(100)$ \\
OVA-IgE & OVA $\times 2$ & $* 16.9 \pm 0.9$ & $15 / 15(100)$ \\
OVA-IgG1 & OVA $\times 2$ & $* 15.1 \pm 1.2$ & $10 / 10(100)$ \\
OVA-IgG2a & OVA $\times 2$ & $3.7 \pm 0.7$ & $0 / 8(0)$ \\
OVA-IgG3 & OVA $\times 2$ & $4.0 \pm 0.5$ & $1 / 8(12.5)$ \\
OVA $/ a l u m$ & OVA $\times 2$ & $* 15.8 \pm 1.0$ & $8 / 8(100)$ \\
B. SJL mice & & & \\
TNP-IgE & OVA $\times 2$ & $3.1 \pm 0.3$ & $0 / 6(0)$ \\
OVA-IgE & OVA $\times 2$ & $* 13.9 \pm 1.1$ & $11 / 11(100)$ \\
& & & \\
\hline
\end{tabular}

Cutaneous reactivity to OVA was determined in groups of mice receiving passive sensitization with specific antibodies or active immunization with OVA/alum. Skin tests were performed $1 \mathrm{~d}$ after completion of airway challenge. After intradermal injection of OVA, the size of the wheal response was assessed 15 min later. A positive test response was defined by active development of a wheal of $\geq 5 \mathrm{~mm}$ in diameter. $* P<0.01$ for wheal diameter compared with nonsensitized control mice.

mined whether BALB/c mice that received anti-OVA $\operatorname{IgE}$ or IgG antibodies would also develop immediate skin test reactivity. Mice injected with anti-OVA IgE or IgG1 developed positive skin test reactions to intradermal injections of OVA regardless of airway challenge; no wheal reactions were observed in nonsensitized mice (injected with control supernatant from the parental myeloma cell line, SP2/0) or mice injected with anti-OVA IgG2a, IgG3, or anti-TNP IgE (Table
III). The responses of mice passively sensitized with anti-OVA $\mathrm{IgE}$ or $\mathrm{IgG} 1$ were similar to the responses of mice immunized with OVA/alum intraperitoneally. Airway exposure to OVA on two consecutive days exerted no influence on skin test reactivity. Intradermal injection of PBS or BSA did not result in wheal formation in any of the mice.

$\mathrm{SJL} / \mathrm{J}$ mice, known to be a low-responder strain for $\mathrm{IgE}$ production (22), also developed positive skin test reactivity after passive sensitization with specific IgE or IgG1 antibodies, similar to BALB/c mice (Table III).

Systemic anaphylaxis in a mouse experimental model with induction of specific IgE is an immediate, frequently fatal reaction after intravenous antigen challenge (12). BALB/c mice, sensitized passively with OVA IgE, rapidly demonstrated respiratory symptoms such as dyspnea and prolongation of expiration a few minutes after intravenous administration of OVA and died within $15 \min (4 / 4$ fatal). The same acute reactions were observed in mice sensitized with anti-OVA $\operatorname{IgG} 1$ (4/4 fatal). None of the mice receiving injections of anti-TNP IgE or IgG1 displayed any symptoms after OVA challenge.

Passive sensitization results in increased $A R$ after antigenspecific challenge via the airways. We monitored $\mathrm{ES}_{50}$ values to compare the effects of passive sensitization with specific antibodies on AR among the different groups. A decrease in the $\mathrm{ES}_{50}$ represents an increase in AR (17). Nonsensitized control $\mathrm{BALB} / \mathrm{c}$ mice had a mean $( \pm \mathrm{SEM}) \mathrm{ES}_{50}$ of $4.0 \pm 0.2 \mathrm{~Hz}$. In mice passively sensitized with anti-OVA IgE supernatants, airway challenge with OVA on two consecutive days resulted in a significant decrease in the $\mathrm{ES}_{50}$ levels to $2.0 \pm 0.2 \mathrm{~Hz}(P<$ $0.001)$. This was similar to the response in mice actively immunized (OVA/alum) and challenged via the airways $(2.3 \pm 0.2$ $\mathrm{Hz}$ ) (Fig. 2). Injection of $\mathrm{IgE}$ in the absence of airway challenge resulted in no significant changes in AR. A single challenge with aerosolized antigen was insufficient to develop airway hyperresponsiveness after passive sensitization with anti-OVA $\mathrm{IgE}$, and two challenges with nebulized OVA alone caused no significant changes in AR (Fig. 2). To test the specificity of the IgE-mediated effect on AR, control culture supernatants from the parental myeloma cell line were administered before OVA

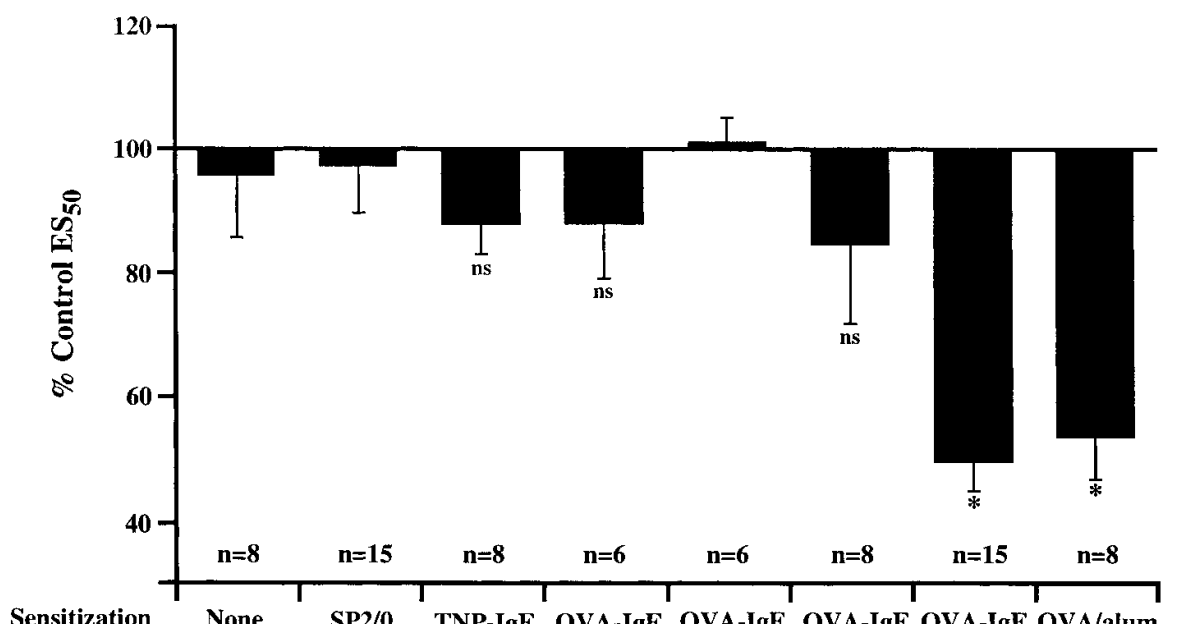

Sensitization None SP2/0 TNP-IgE OVA-IgE OVA-IgE OVA-IgE OVA-IgE OVA/alum

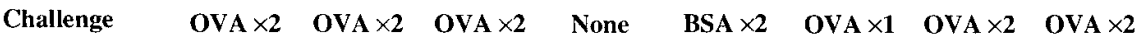

Figure 2. Passive sensitization with specific IgE causes airway hyperresponsiveness after antigen challenge via the airways. AR was analyzed in several groups of mice injected with control supernatant from the parental myeloma cell line (SP2/0), mice passively sensitized with TNP-specific IgE (TNP-IgE) or OVA-specific IgE (OVAIgE), or mice actively immunized with OVA/alum (intraperitoneal OVA), followed by airway challenge with nebulized antigen on $1 \mathrm{~d}(\mathrm{OVA} \times 1)$ or on two consecutive days $(\mathrm{OVA} \times 2$ or BSA $\times 2$ ). AR was analyzed $2 \mathrm{~d}$ after completion of airway challenge by electrical field stimulation of tracheal smooth muscle preparations. AR is expressed as a percentage of control $\mathrm{ES}_{50}$. The mean $( \pm \mathrm{SEM}) \mathrm{ES}_{50}$ for nonsensitized control animals $(n=22)$ was $4.0 \pm 0.2$ $\mathrm{Hz}$, and this value was taken as $100 \%$. Presented are the means \pm SEM for each group from independent experiments using three to four mice in each group in each experiment. *Significant differences compared with nonsensitized controls $(P<0.01)$ and all other experimental groups $(P<0.05)$. $n s$, not significant. 


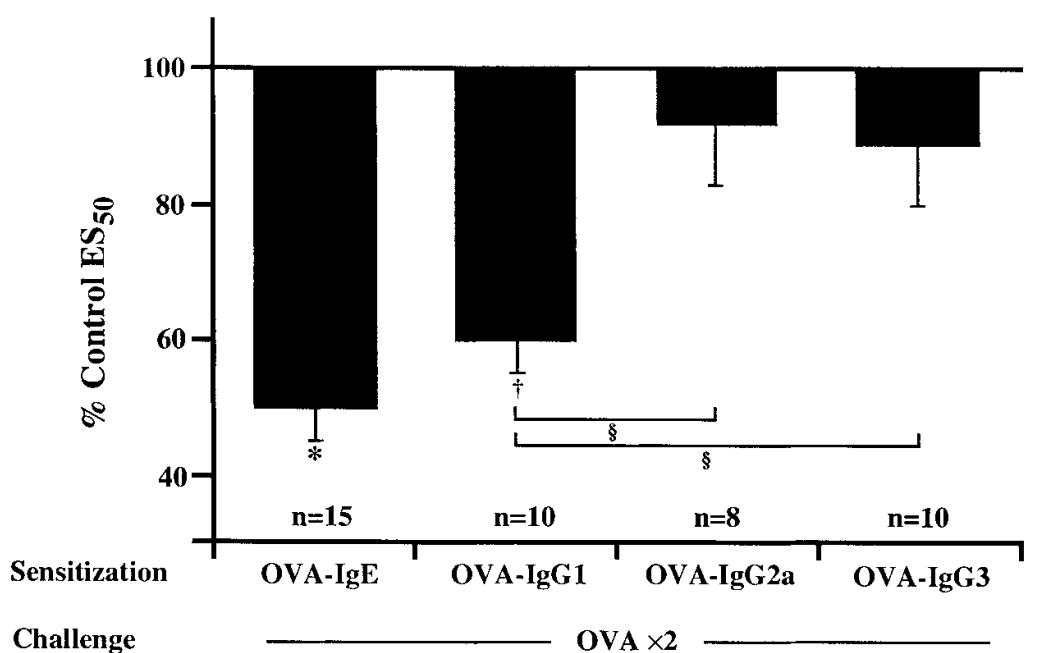

Figure 3. Passive sensitization with specific IgG1 but not IgG2a and IgG3 causes airway hyperresponsiveness after antigen challenge via the airways. Groups of mice were passively sensitized with OVA-specific $\operatorname{IgG} 1$, IgG2a, or IgG3 antibody (OVA-IgG1, OVA-IgG2a, or OVA-IgG3, respectively) and challenged with nebulized OVA on two consecutive days. AR was expressed as a percentage of control $\mathrm{ES}_{50}$ and compared with the value for the mice passively sensitized with antiOVA IgE as described in Fig. 1. Presented are the means \pm SEM for each group from independent experiments using three to four mice in each group in each experiment. ${ }^{*}$ Significant differences $(* P<0.001$ and $\left.{ }^{\dagger} P<0.005\right)$ compared with nonsensitized control mice. ${ }^{\S}$ Significant differences between the groups $(P<0.05)$. challenge, and intravenous injection of $\operatorname{IgE}$ antibodies was combined with airway challenge with an irrelevant antigen (BSA). Mice passively sensitized with OVA-specific IgE developed airway hyperresponsiveness only when followed by airway exposure to the corresponding antigen, demonstrating the specificity of IgE-induced responses in the airways (Fig. 2).

The ability of anti-OVA IgG antibodies to alter AR was evaluated after exposure to nebulized OVA. Only mice passively sensitized by two injections of anti-OVA IgG1 antibody but not IgG2a or IgG3 antibodies (even after five injections) resulted in an increase in AR after airway challenge (Fig. 3).

$\mathrm{SJL} / \mathrm{J}$ mice were passively sensitized with monoclonal IgE antibodies and challenged with antigen via the airways. Mice passively sensitized with anti-OVA IgE also developed airway hyperresponsiveness after airway exposure to OVA to a degree comparable to that of BALB/c mice sensitized and challenged in the same way (Fig. 4).

Effect of passive sensitization on cell composition in $B A L$ fluid after airway challenge. Total leukocyte counts and differential cell counts in BAL fluid of individual mice were assessed in passively or actively sensitized mice. The numbers of total leukocytes and macrophages recovered from BAL were significantly higher in passively and actively immunized mice after two airway challenges compared with nonsensitized mice (airway challenge alone) (Fig. 5). Lymphocytes and neutrophils were significantly increased in the mice actively (intraperitoneally) immunized but not in passively sensitized animals. In the groups passively sensitized with specific $\operatorname{IgE}$ or IgG1, statistically larger numbers of eosinophils were observed compared with the nonsensitized group in which no eosinophils were detected. The intraperitoneally immunized group showed a larger number of eosinophils than the passively sensitized groups. The group receiving injections of anti-TNP IgE showed no difference in absolute counts for leukocytes in BAL from the nonsensitized controls. Passive sensitization alone or together with a single challenge, or active immunization alone, did not affect the leukocyte counts (data not shown).

Effect of passive sensitization on composition of lung cells after airway challenge. Total leukocyte counts and differential counts for cells retrieved from lung tissue of individual mice were compared for nonsensitized and actively and passively
(anti-OVA IgE) sensitized mice after airway challenge. There were no differences in total leukocyte counts among the groups (Fig. 6). The absolute numbers of macrophages/monocytes were lower in both sensitized groups compared with nonsensitized mice. The lymphocyte numbers were increased in the passively sensitized group, and neutrophil numbers were increased in the actively immunized group. Significant numbers of eosinophils were detected in both of the sensitized groups compared with the controls. Passive sensitization alone
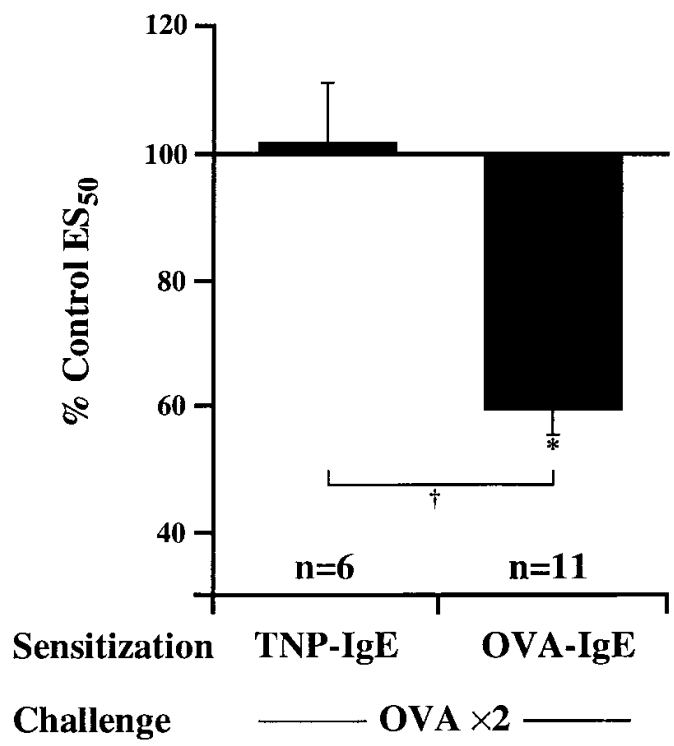

Figure 4. SJL mice passively sensitized with specific IgE develop airway hyperresponsiveness after airway challenge. SJL mice were passively sensitized with TNP-specific IgE (TNP-IgE) or OVA-specific IgE (OVA-IgE) and exposed to nebulized OVA on two consecutive days. AR was expressed as a percentage of control $\mathrm{ES}_{50}$. The mean $\left( \pm\right.$ SEM) $\mathrm{ES}_{50}$ for nonsensitized control animals $(n=12)$ was $4.9 \pm 0.6 \mathrm{~Hz}$, and this value was taken as $100 \%$. Presented are the means \pm SEM for each group from independent experiments using three to four mice in each group in each experiment. $* P<0.01 \mathrm{com}-$ pared with nonsensitized control. ${ }^{\dagger}$ Significant difference between the groups $(P<0.05)$. 


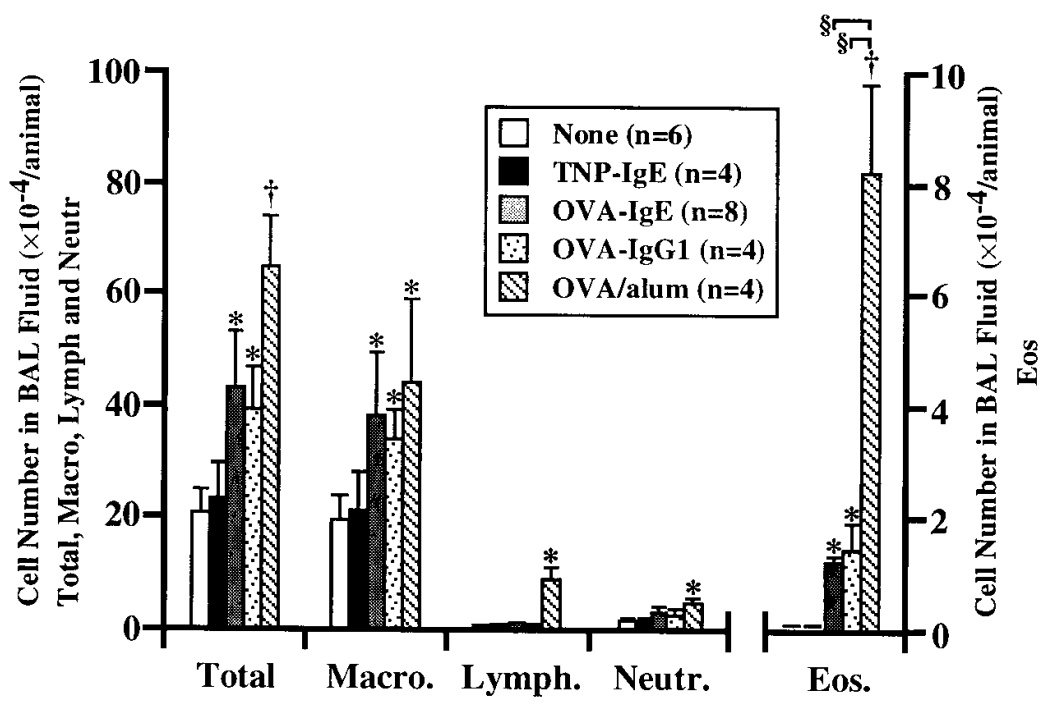

Figure 5. Cellular composition in BAL fluid. Absolute numbers of leukocytes recovered in BAL fluid per mouse were determined in groups of mice that received two airway challenges with OVA: nonsensitized mice (None), mice receiving passive sensitization with anti-TNP IgE (TNP-IgE), anti-OVA IgE (OVA-IgE) or anti-OVA IgG1 (OVA-IgG1), or mice actively immunized with OVA/alum (intraperitoneal OVA). BAL were performed $1 \mathrm{~d}$ after completion of airway challenge. Presented are the means \pm SD of the indicated number of mice from independent experiments using three to four mice in each group in each experiment. ${ }^{*}$ Significant differences $\left({ }^{*} P<0.05\right.$ and ${ }^{\dagger} P<0.01$ ) compared with nonsensitized control mice. ${ }^{\S}$ Significant differences between the groups $(P<0.05)$. or together with a single challenge did not affect the leukocyte counts (data not shown).

Effect of passive sensitization on eosinophil counts in lung sections after airway challenge. Histological examination was performed $1 \mathrm{~d}$ after the last airway challenge with OVA, and eosinophil counts in peribronchial regions were assessed in nonsensitized and in passively (with anti-OVA IgE) sensitized mice after airway challenge. In passively sensitized mice receiving two airway exposures to OVA, multifocal infiltrates of inflammatory cells were observed predominantly in the submucosa of bronchi (and bronchioli). Passively sensitized mice demonstrated significantly higher numbers of eosinophils in the peribronchial areas compared with nonsensitized mice after two airway challenges (Fig. 7). In mice receiving passive sensitization and a single airway challenge, there was no significant increase in eosinophil numbers. Passive sensitization alone had no effect on eosinophil counts in the lung tissue.

Effect of passive sensitization on EPO levels in supernatants of BAL fluid and lung cells. EPO activities in the supernatants of BAL fluid and the lysed pellets of cells extracted from the lungs were determined in nonsensitized or sensitized mice after antigen challenge via the airways. Active immunization (OVA/alum) and airway challenge resulted in a significant increase in EPO levels in the supernatants of BAL fluid and in the pellets of cells isolated from lung tissue (Fig. 7). In the group receiving passive sensitization with specific IgE, a significant increase in EPO activity was observed in the pellets of lung cells but not in BAL fluid.

\section{Discussion}

The relationship between IgE-mediated mast cell activation, eosinophil accumulation, and $\mathrm{T}$ cell recruitment in chronic inflammation of the airways is not well defined. In previous studies, we demonstrated in $\mathrm{BALB} / \mathrm{c}$ mice that repeated exposure to antigenic proteins such as OVA or ragweed induced an antigen-specific IgE response and emphasized that different $\mathrm{T}$ cell populations from sensitized mice play regulatory roles in $\mathrm{IgE}$ production $(7,8)$. In each case, the $\operatorname{IgE}$ response was consistently associated with the acquisition of immediate cutaneous hypersensitivity (9) and the development of increased AR (17). In contrast, in SJL/J mice, where the mice failed to gener-

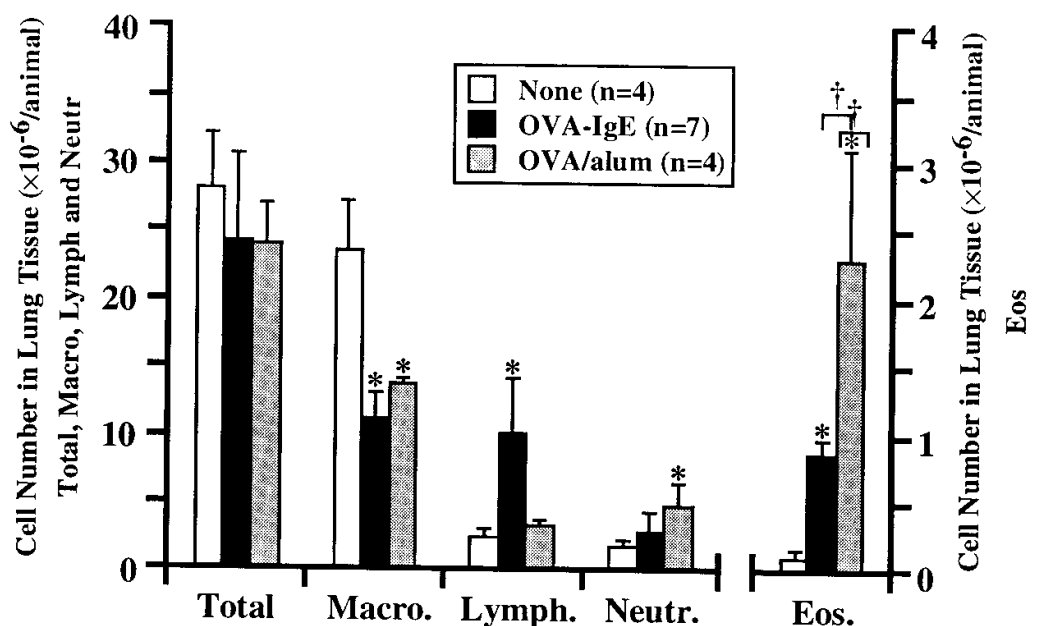

Figure 6. Composition of cells extracted from the lungs. Absolute numbers of leukocytes retrieved from lung tissue per mouse were determined in groups of mice after two airway challenges with OVA: nonsensitized mice (None), mice passively sensitized with antiOVA IgE (OVA-IgE), or mice actively immunized with OVA/alum (intraperitoneal OVA). Lung cells were isolated by lung tissue digestion after performing BAL and lung perfusion $1 \mathrm{~d}$ after the last airway challenge. Presented are the means \pm SD of the indicated number of mice from independent experiments using three to four mice in each group in each experiment. $* P<0.05$ compared with nonsensitized control mice. ${ }^{\dagger}$ Significant difference between the groups $(P<0.05)$. 


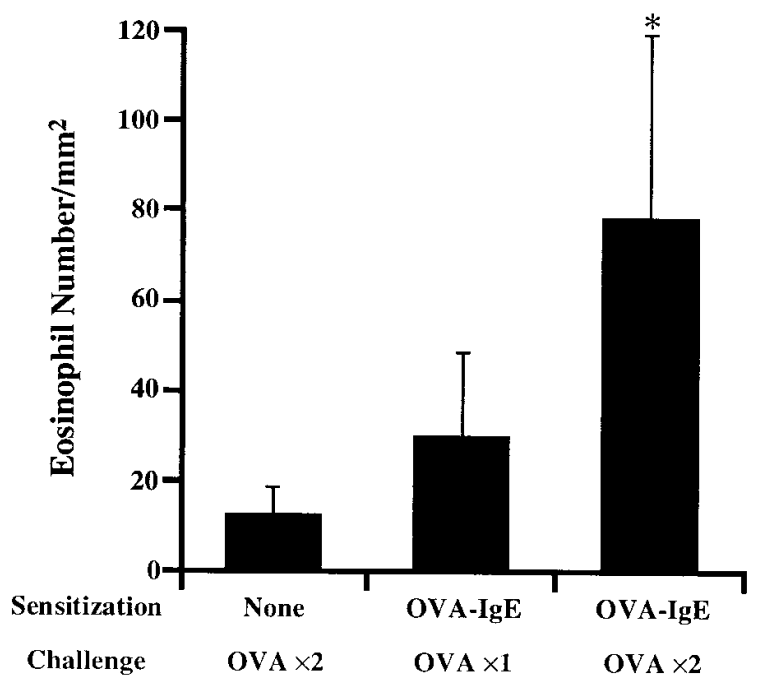

Figure 7. Eosinophil counts in peribronchial regions. Numbers of eosinophils observed in the peribronchial areas in the lung sections were determined in the following groups of mice: nonsensitized mice receiving two airway challenges with OVA (None) or mice passively sensitized with anti-OVA IgE (OVA-IgE) and receiving one or two airway challenges with OVA. Presented are the means \pm SD of four mice from two independent experiments in each group. ${ }^{*} P<0.05$ compared with nonsensitized control mice.

ate $\mathrm{IgE}$ responses under the same sensitization protocol, no alterations in AR were observed, further implying an association between $\mathrm{IgE}$ responses and increased AR (17). However, the role of $\mathrm{IgE}$ in triggering altered $\mathrm{AR}$, especially interactions with antigen-specific $\mathrm{T}$ cells, still remains to be clarified.

The purpose of the present study was to define the role of $\mathrm{IgE}$ (or IgG1) antibody in the development of airway hyperresponsiveness and eosinophil infiltration. To this end, antigenspecific B cell hybridomas were generated, secreting antibodies of different isotypes. The ability to sensitize mice passively in this way obviated the need for repeated antigen exposure via the airways to generate an $\operatorname{IgE}$ response, which prevented critical analysis of the components contributing to the alterations in AR. Passive sensitization with anti-OVA IgE predictably resulted in immediate wheal responses to intradermal injection of antigen and positive PCA reactions. In the absence of airway challenge with the relevant (concordant) antigen, passive sensitization with $\operatorname{IgE}$ was insufficient to elicit airway changes. This confirmed previous studies in SJL mice (17) and in $\mathrm{BALB} / \mathrm{c}$ mice sensitized to OVA via the skin to elicit an $\mathrm{IgE}$ response but no altered AR (23). In fact, two exposures to OVA via the airways was required after passive sensitization with IgE anti-OVA antibody to trigger alterations in AR. The response was specific in that IgE anti-TNP antibody coupled with OVA exposure was not effective, nor was airway exposure alone on two occasions in the absence of passive sensitization. In previous reports using animal models of antigeninduced airway hyperreactivity, increases in eosinophils were demonstrated in both BAL fluid and lung cells recovered from lung digestion and correlated with increased AR (24-26). Passively sensitized and challenged mice also demonstrated increased numbers of eosinophils in the peribronchial regions and increased EPO levels in the lung tissue, indicating that the combination of passive sensitization with $\operatorname{IgE}$ and limited airway exposure to antigen is sufficient to elicit inflammatory changes coupled with development of airway hyperresponsiveness. These increases in AR as measured by electrical field stimulation in allergen-sensitized mice after airway challenge have been shown to correlate with an increase in acetylcholine release from neural terminals, presumably based on altered neural control of airways and/or dysfunction of the M2 muscarinic autoreceptor (27).

The extent of these changes after passive sensitization were similar to what we observed in animals actively immunized (intraperitoneally) with the combination of OVA/alum before airway challenge. In both cases, increased numbers of macrophages were detected in BAL fluid from sensitized mice, whereas lower numbers were demonstrated in lung tissue. The
A

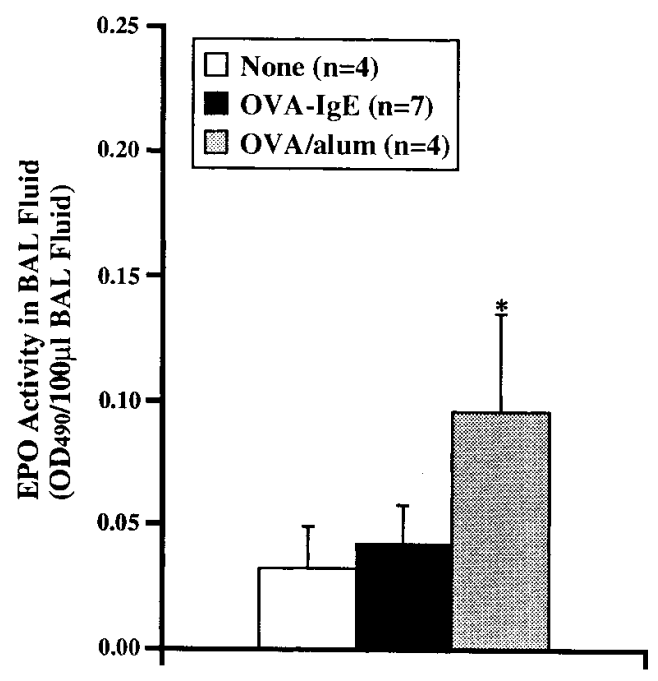

B

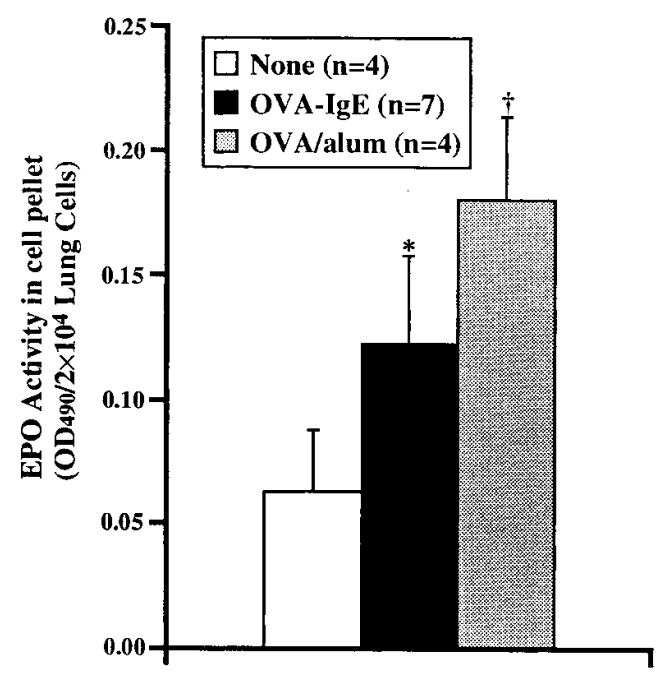

Figure 8. EPO levels in supernatants of BAL fluid and pellets of lung cells. EPO activity was measured in the supernatants of BAL fluid $(A)$ and the lysed pellets of lung cells $(B)$ in samples obtained from the same groups of mice described in Fig. 5. Presented are the means \pm SD. ${ }^{*}$ Significant differences $\left({ }^{*} P<0.05\right.$ and $\left.{ }^{\dagger} P<0.01\right)$ compared with nonsensitized control mice. 
major differences were that, although actively immunized mice demonstrated lower IgE levels, significantly higher neutrophil and eosinophil numbers were demonstrated in lung tissue and BAL fluid. Changes in AR were similar. One possible explanation for the discordance between levels of increased AR and eosinophil numbers observed in passively and actively sensitized mice is that the degree of eosinophil accumulation may not parallel the development of airway hyperresponsiveness. Previous studies showed that eosinophil activation rather than accumulation in local tissue is correlated to increased AR (28), whereas, in our study, eosinophil activation in the lung tissue as measured by EPO activities appeared to be associated with the development of airway hyperresponsiveness. The failure of $\mathrm{IgE}$ levels to correlate directly with eosinophil numbers suggests that additional factors influence eosinophil recruitment to the lung and airways. The greater eosinophil recruitment in actively immunized animals after airway challenge compared with passively sensitized mice could be explained by the degree of activation of antigen-specific $\mathrm{T}$ cells. Activated $\mathrm{T}$ cells are thought to contribute to the inflammatory response, releasing cytokines that mediate eosinophil recruitment and activation. The finding that neither passive sensitization alone nor two challenges with the relevant antigen alone were sufficient to induce airway hyperresponsiveness may relate to whether limited airway challenges can trigger the activation of antigenspecific $T$ cells in the absence of passive sensitization. Peribronchial lymph node and spleen cells from actively immunized mice proliferated in response to OVA in a dose-dependent manner, as we previously showed (7). A single airway challenge with antigen combined with passive transfer of $\operatorname{IgE}$ failed to induce an eosinophil response in the lung or BAL or alteration in AR. Peribronchial lymph node and spleen cells from mice passively sensitized with anti-OVA antibodies and challenged on one occasion showed no significant proliferative responses to OVA $2 \mathrm{~d}$ after OVA challenge via the airway. It is possible that limited local exposure to antigen does indeed induce the recruitment and activation of antigen-specific $\mathrm{T}$ cells, but they are not detectable in proliferative assays. Passive sensitization combined with two or more challenges with OVA was shown to induce an antigen-specific proliferative response (three- to fivefold over baseline response) in peribronchial lymph node cells. These data suggest that antigen exposure via the airways on two consecutive days alone could be insufficient to expand specific $\mathrm{T}$ cells and that the combination of $\operatorname{IgE}$ with antigen could augment the responses mediated by antigen-specific T cells.

At present it is not entirely clear how $\operatorname{IgE}$ (or $\mathrm{IgG} 1$ ) may result in the heightened antigen-specific $\mathrm{T}$ cell responses. $\mathrm{B}$ cells or other antigen-presenting cells (e.g., dendritic cells) may bind antigen via specific antibody interactions with Fc receptors expressed on the surface of these cells. In this way, such cells demonstrate a high capacity for antigen presentation of the relevant antigen $(29,30)$. Cells expressing $\operatorname{IgE}$ receptors, FceRI or FceRII, have shown IgE-dependent targeting of allergens to antigen-presenting cells with enhancement of antigen-specific $T$ cell responses $(31,32)$. In addition to enhancing $\mathrm{T}$ cell responsiveness, IgE (or IgG1) antibodies have been shown to enhance the recruitment of effector $\mathrm{T}$ cells to the site of local challenge with specific antigen (33).

The role of $\mathrm{IgE}$ in mediating allergic inflammation may be at several additional levels. The capability of IgE-mediated mast cell activation to induce allergic inflammation directly is supported by the observation that intradermal administration of anti-IgE antibody can induce late-phase reactions as well as immediate cutaneous reactions (34). It has been reported that mast cells release cytokines such as TNF- $\alpha$, IL-3, and IL-4 (3537). These cytokines could activate and recruit eosinophils to the airways. Another possibility is that FceRs are involved in regulating allergic inflammation, especially the low-affinity $F c \in R$ (FceRII/CD23). These receptors have been demonstrated on various types of cells that can participate in allergic responses $(1,38)$. Interactions between antigen and $\mathrm{IgE}$ passively transferred and bound to FceRII on these effector cells could play a substantial role in allergic inflammation. Recent studies have demonstrated release of EPO from purified eosinophils from patients with parasitic infection or an allergic disease (39). Activation of a respiratory burst in neutrophils incubated with $\operatorname{IgE}$ after addition of anti-IgE antibody has also been observed, suggesting that cross-linking of antigen-specific $\mathrm{IgE}$ bound to receptors on the cell surface could activate these cells (40).

These results defining a role for $\mathrm{IgE}$ in altered $\mathrm{AR}$ both support and conflict with data using other approaches from other laboratories. In rats passively sensitized with $\mathrm{IgE}$, acute bronchoconstriction and increased vascular permeability have been observed in the airways after antigen challenge $(41,42)$. We also observed dyspnea and fatal anaphylactic reactions in mice passively sensitized with anti-OVA IgE and challenged with OVA intravenously. In other studies using rats (42), passive sensitization with IgE anti-DNP antibody resulted in no increases in resistance or inflammation when challenged with antigen via the airways; this contrasted with rats actively immunized with OVA/alum where airway challenge resulted in increases in resistance. In rabbits, infusion of antigen-specific rabbit homocytotropic (IgE) antibody also resulted in latephase reaction after airway challenge (11).

$\mathrm{SJL} / \mathrm{J}$ mice passively sensitized with IgE also developed immediate hypersensitivity responses and increased AR. This strain is known to be a low IgE responder because of diminished capacity for IL-4 synthesis (22). Bypassing this deficiency (passive sensitization) resulted in the full ability of these mice to develop alterations in AR and in inflammatory changes similar to those of the BALB/c mice. This implies that, although deficient in $\mathrm{V}_{\beta} 8 \mathrm{~T}$ cells (the primary expanded population in response to OVA in BALB/c mice [43]) and capable of only limited IL-4 production, these mice can develop allergic inflammatory changes and, as a consequence, altered AR, when given specific $\mathrm{IgE}$ antibody.

This is the first demonstration that antigen-specific IgG1 antibodies are not only capable of causing immediate hypersensitivity but are also effective in inducing airway hyperresponsiveness. As described above, IgG1, similar to $\operatorname{IgE}$, can enhance $\mathrm{T}$ cell responsiveness and recruit effector $\mathrm{T}$ cells to the site of local antigen challenge in mice. Mouse IgG1 can mediate both in vivo PCA reactions and in vitro mast cell sensitization $(13,44)$. The observation (12) that IgE-deficient mice immunized with OVA still develop systemic anaphylaxis reactions after intravenous antigen challenge suggests the presence of alternative pathways of immediate hypersensitivity, and that IgG1 is one of the candidates that mediates systemic allergic reactions. At present, there is no known analogue of murine IgG1, and whether a second Ig isotype (in addition to $\mathrm{IgE}$ ) can mediate such changes in airway responsiveness in humans is unknown at present. Conventional sensi- 
tization protocols cannot distinguish between $\operatorname{IgG} 1$ and $\operatorname{IgE}$ antibodies, but passive sensitization with $\mathrm{mAbs}$ enabled us to analyze the individual activities of each IgG subclass after systemic or local exposure to antigen. We observed immediate anaphylaxis reactions in IgG1-sensitized mice after intravenous challenge with antigen, similar to the IgE-sensitized animals. PCA titers of anti-OVA IgG1 were lower than those of anti-OVA $\operatorname{IgE}$ at the same protein concentrations and despite slightly higher affinity, paralleling the finding that two injections of anti-OVA IgG1 were required to obtain equal levels of immediate cutaneous reactivity as induced by a single injection of anti-OVA IgE. The findings with IgG1 antibodies contrasted with the absence of activity of anti-OVA IgG2a and IgG3 antibodies with similar anti-OVA affinities; with the latter, no significant changes in skin hypersensitivity reactions or AR were observed. The expression of IgG Fc receptors has been reported not only on mast cells but also on other effector cells such as macrophages, eosinophils, and platelets $(45,46)$. In an analogous fashion to IgE, IgG1 antibodies, through interactions with these receptors, may play a direct or indirect role in the development of allergic inflammation and recruitment of T cells.

In summary, these data identify an essential role for $\operatorname{IgE}$ (or IgG1) antibodies in a murine model of allergen sensitization via the airways. Alone, these antibodies are unable to alter AR, but in combination with limited airway exposure to antigen they elicit eosinophil infiltration of the lungs, increased EPO activity, and altered AR. Further studies will define the role of these antibodies in mast cell activation, cytokine production, or $\mathrm{T}$ cell recruitment to the airways.

\section{Acknowledgments}

The authors thank Dr. A.H. Liu for guidance in generating B cell hybridomas and Dr. Peter Henson for review of the manuscript. The assistance of Mrs. Debbie Remley in the preparation of this manuscript is gratefully acknowledged.

This work was supported by grants AI-29704 (E.W. Gelfand) and P01-HL36577 (E.W. Gelfand and G.L. Larson) from the National Institutes of Health.

\section{References}

1. Zweiman, B. 1993. The late-phase reaction: role of IgE, its receptor and cytokines. Curr. Opin. Immunol. 5:950-955.

2. Muller, K.M., F. Jaunin, I. Masouye, J.H. Saurat, and C. Hauser. 1993. Th2 cells mediate IL-4-dependent local tissue inflammation. J. Immunol. 150: $5576-5584$.

3. Bradley, B.L., M. Azzawi, M. Jacobson, B. Assoufi, J.V. Collins, A.M. Irani, L.B. Schwartz, S.R. Durham, P.K. Jeffery, and A.B. Kay. 1991. Eosinophils, T-lymphocytes, mast cells, neutrophils, and macrophages in bronchial biopsy specimens from atopic subjects with asthma: comparison with biopsy specimens from atopic subjects without asthma and normal control subjects and relationship to bronchial hyperresponsiveness. J. Allergy Clin. Immunol. 88: 661-674

4. Bentley, A.M., G. Menz, C. Storz, D.S. Robinson, B. Bradley, P.K. Jeffery, S.R. Durham, and A.B. Kay. 1992. Identification of T lymphocytes, macrophages, and activated eosinophils in the bronchial mucosa in intrinsic asthma. Relationship to symptoms and bronchial responsiveness. Am. Rev. Respir. Dis. 146:500-506.

5. Robinson, D.S., Q. Hamid, S. Ying, A. Tsicopoulos, J. Barkans, A.M. Bentley, C. Corrigan, S.R. Durham, and A.B. Kay. 1992. Predominant TH2-like bronchoalveolar T-lymphocyte population in atopic asthma. N. Engl. J. Med. 326:298-304

6. Corrigan, C.J., and A.B. Kay. 1992. T cells and eosinophils in the pathogenesis of asthma. Immunol. Today. 13:501-507.

7. Renz, H., H.R. Smith, J.E. Henson, B.S. Ray, C.G. Irvin, and E.W. Gelfand. 1992. Aerosolized antigen exposure without adjuvant causes increased
IgE production and increased airway responsiveness in the mouse. J. Allergy Clin. Immunol. 89:1127-1138.

8. Renz, H., J. Saloga, K.L. Bradley, J.E. Loader, J.L. Greenstein, G. Larsen, and E.W. Gelfand. 1993. Specific V beta T cell subsets mediate the immediate hypersensitivity response to ragweed allergen. J. Immunol. 151:19071917

9. Saloga, J., H. Renz, G. Lack, K.L. Bradley, J.L. Greenstein, G. Larsen, and E.W. Gelfand. 1993. Development and transfer of immediate cutaneous hypersensitivity in mice exposed to aerosolized antigen. J. Clin. Invest. 91:133140

10. Waserman, S., R. Olivenstein, P. Renzi, L.J. Xu, and J.G. Martin. 1992. The relationship between late asthmatic responses and antigen-specific immunoglobulin. J. Allergy Clin. Immunol. 90:661-669.

11. Behrens, B.L., R.A. Clark, W. Marsh, and G.L. Larsen. 1984. Modulation of the late asthmatic response by antigen-specific immunoglobulin $\mathrm{G}$ in an animal model. Am. Rev. Respir. Dis. 130:1134-1139.

12. Oettgen, H.C., T.R. Martin, B.A. Wynshaw, C. Deng, J.M. Drazen, and P. Leder. 1994. Active anaphylaxis in IgE-deficient mice. Nature (Lond.). 370: 367-370.

13. Ovary, Z., N.M. Vaz, and N.L. Warner. 1970. Passive anaphylaxis in mice with gamma-G antibodies. V. Competitive effects of different immunoglobulins and inhibition of reactions with antiglobulin sera. Immunology. 19:715727

14. Daeron, M., D.A. Prouvost, and G.A. Voisin. 1980. Mast cell membrane antigens and $\mathrm{Fc}$ receptors in anaphylaxis. II. Functionally distinct receptors for $\mathrm{IgG}$ and for IgE on mouse mast cells. Cell. Immunol. 49:178-189.

15. Rittenberg, M.B., and A.A. Amkraut. 1966. Immunogenicity of trinitrophenyl-hemocyanin: production of primary and secondary anti-hapten precipitins. J. Immunol. 97:421-430.

16. Gefter, M.L., D.H. Margulies, and M.D. Scharff. 1977. A simple method for polyethylene glycol-promoted hybridization of mouse myeloma cells. Somatic Cell Genet. 3:231-236.

17. Larsen, G.L., H. Renz, J.E. Loader, K.L. Bradley, and E.W. Gelfand. 1992. Airway response to electrical field stimulation in sensitized inbred mice. Passive transfer of increased responsiveness with peribronchial lymph nodes. $J$. Clin. Invest. 89:747-752.

18. Lavnikova, N., J.C. Drapier, and D.L. Laskin. 1993. A single exogenous stimulus activates resident rat macrophages for nitric oxide production and tumor cytotoxicity. J. Leukocyte Biol. 54:322-328.

19. Duffy, J.B., P. Smith, J. Crocker, and H.R. Matthews. 1993. Combined staining method for the demonstration of tissue eosinophils and mast cells. $J$. Histotechnology. 16:143-148.

20. Strath, M., D.J. Warren, and C.J. Sanderson. 1985. Detection of eosinophils using an eosinophil peroxidase assay. Its use as an assay for eosinophil differentiation factors. J. Immunol. Methods. 83:209-215.

21. Rothstein, T.L., and M.L. Gefter. 1983. Affinity analysis of idiotypepositive and idiotype-negative Ars-binding hybridoma proteins and Arsimmune sera. Mol. Immunol. 20:161-168.

22. Holt, P.G., A.H. Rose, J.E. Batty, and K.J. Turner. 1981. Induction of adjuvant-independent IgE responses in inbred mice: primary, secondary, and persistent IgE responses to ovalbumin and ovomucoid. Int. Arch. Allergy Appl. Immunol. 65:42-50.

23. Saloga, J., H. Renz, G.L. Larsen, and E.W. Gelfand. 1994. Increased airways responsiveness in mice depends on local challenge with antigen. Am. J. Respir. Crit. Care Med. 149:65-70.

24. Gavett, S.H., X. Chen, F. Finkelman, and K.M. Wills. 1994. Depletion of murine $\mathrm{CD}^{+} \mathrm{T}$ lymphocytes prevents antigen-induced airway hyperreactivity and pulmonary eosinophilia. Am. J. Respir. Cell Mol. Biol. 10:587-593.

25. Renzi, P.M., R. Olivenstein, and J.G. Martin. 1993. Effect of dexamethasone on airway inflammation and responsiveness after antigen challenge of the rat. Am. Rev. Respir. Dis. 148:932-939.

26. Laberge, S., H. Rabb, T.B. Issekutz, and J.G. Martin. 1995. Role of VLA-4 and LFA-1 in allergen-induced airway hyperresponsiveness and lung inflammation in the rat. Am. J. Respir. Crit. Care Med. 151:822-829.

27. Larsen, G.L., T.M. Fame, H. Renz, J.E. Loader, J. Graves, M. Hill, and E.W. Gelfand. 1994. Increased acetylcholine release in tracheas from allergenexposed IgE- immune mice. Am. J. Physiol. 266:1263-1270.

28. Pretolani, M., C. Ruffie, D. Joseph, M.G. Campos, M.K. Church, J. Lefort, and B.B. Vargaftig. 1994. Role of eosinophil activation in the bronchial reactivity of allergic guinea pigs. Am. J. Respir. Crit. Care Med. 149:1167-1174.

29. Malynn, B.A., and H.H. Wortis. 1984. Role of antigen-specific B cells in the induction of SRBC-specific T cell proliferation. J. Immunol. 132:2253-2258.

30. Rock, K.L., B. Benacerraf, and A.K. Abbas. 1984. Antigen presentation by hapten-specific B lymphocytes. I. Role of surface immunoglobulin receptors. J. Exp. Med. 160:1102-1113.

31. Maurer, D., C. Ebner, B. Reininger, E. Fiebiger, D. Kraft, J.P. Kinet, and G. Stingl. 1995. The high affinity $\mathrm{IgE}$ receptor (FceRI) mediates $\mathrm{IgE}$ dependent allergen presentation. J. Immunol. 154:6285-6290.

32. Kehry, M.R., and L.C. Yamashita. 1989. Low-affinity IgE receptor (CD23) function on mouse B cells: role in IgE-dependent antigen focusing. Proc. Natl. Acad. Sci. USA. 86:7556-7560.

33. Ptak, W., G.P. Geba, and P.W. Askenase. 1991. Initiation of delayed- 
type hypersensitivity by low doses of monoclonal $\operatorname{IgE}$ antibody. Mediation by serotonin and inhibition by histamine. J. Immunol. 146:3929-3936.

34. Dolovich, J., F.E. Hargreave, R. Chalmers, K.J. Shier, J. Gauldie, and J. Bienenstock. 1973. Late cutaneous allergic responses in isolated IgE-dependent reactions. J. Allergy Clin. Immunol. 52:38-46.

35. Young, J.D., C.C. Liu, G. Butler, Z.A. Cohn, and S.J. Galli. 1987. Identification, purification, and characterization of a mast cell-associated cytolytic factor related to tumor necrosis factor. Proc. Natl. Acad. Sci. USA. 84:91759179.

36. Brown, M.A., J.H. Pierce, C.J. Watson, J. Falco, J.N. Ihle, and W.E. Paul. 1987. B cell stimulatory factor-1/interleukin-4 mRNA is expressed by normal and transformed mast cells. Cell. 50:809-818.

37. Humphries, R.K., S. Abraham, G. Krystal, P. Lansdorp, F. Lemoine, and C.J. Eaves. 1988. Activation of multiple hemopoietic growth factor genes in Abelson virus-transformed myeloid cells. Exp. Hematol. 16:774-781.

38. Conrad, D.H., C.M. Squire, W.C. Bartlett, and S.E. Dierks. 1991. Fcє receptors. Curr. Opin. Immunol. 3:859-864.

39. Tomassini, M., A. Tsicopoulos, P.C. Tai, V. Gruart, A.B. Tonnel, L. Prin, A. Capron, and M. Capron. 1991. Release of granule proteins by eosinophils from allergic and nonallergic patients with eosinophilia on immunoglobu- lin-dependent activation. J. Allergy Clin. Immunol. 88:365-375.

40. Truong, M.J., V. Gruart, J.P. Kusnierz, J.P. Papin, S. Loiseau, A. Capron, and M. Capron. 1993. Human neutrophils express immunoglobulin E (IgE)-binding proteins (Mac-2/€ BP) of the S-type lectin family: role in $\mathrm{IgE}$ dependent activation. J. Exp. Med. 177:243-248.

41. Sertl, K., M.L. Kowalski, J. Slater, and M.A. Kaliner. 1988. Passive sensitization and antigen challenge increase vascular permeability in rat airways. Am. Rev. Respir. Dis. 138:1295-1299.

42. Sorkness, R., K. Johns, W.L. Castleman, and R.J. Lemanske. 1990. Late pulmonary allergic responses in actively but not passively IgE-sensitized rats. $J$. Appl. Physiol. 69:1012-1021.

43. Renz, H., and E.W. Gelfand. 1992. T-cell receptor V elements regulate murine IgE production and airways responsiveness. Allergy (Cph.). 47:270-276.

44. Tigelaar, R.E., N.M. Vaz, and Z. Ovary. 1971. Immunoglobulin receptors on mouse mast cells. J Immunol. 106:661-672.

45. Dessaint, J.P., and A. Capron. 1989. IgE and inflammatory cells: the cellular networks in allergy. Int. Arch. Allergy Appl. Immunol. 1:28-31.

46. Capron, M., A. Capron, E.J. Goetzl, and K.F. Austen. 1981. Tetrapeptides of the eosinophil chemotactic factor of anaphylaxis (ECF-A) enhance eosinophil Fc receptor. Nature (Lond.). 289:71-73. 